Volume 4 Issue 1, March 2019: pp. 1-10. Copyright @ LamLaj. Faculty of Law, Lambung Mangkurat University, Banjarmasin, South Kalimantan, Indonesia. ISSN: 2502-3136 | e-ISSN: 2502-3128. Open Access at: http://lamlaj.ulm.ac.id/web/

\title{
IMPLIKASI HUKUM PROGRAM PERCEPATAN PENDAFTARAN TANAH DALAM KEBIJAKAN REFORMA AGRARIA (PROGRAM SERTIPIKAT TANAH SISTEMATIS LENGKAP)
}

\author{
Erlina $^{1}$, Nurfitria Atikarani \\ Fakultas Hukum Universitas Lambung Mangkurat. Jl.Brigjen H.Hasan Basri \\ Banjarmasin, 70123 Indonesia Fax: (0511)4321658+E-mail: erlina_fhunlam@yahoo.co.id \\ Fakultas Hukum Universitas Lambung Mangkurat. Jl.Brigjen H.Hasan Basri \\ Banjarmasin, 70123 Indonesia Fax: (0511)4321658+E-mail: ryaculobong@gmail.com
}

Submitted : 12/02/2019 Reviewed: 07/03/2019 Accepted:29/03/2019

\begin{abstract}
The aim of this study was to determine the synchronization of Government Regulation Number 24 of 1997 with Ministerial Regulation Number 6 of 2018 and the Implications of the certificate of land rights with the Ministerial Regulation Number 6 of 2018 on the certainty of ownership of the land. The results of the study show that: First, Government Regulation Number 24 of 1997 concerning Land Registration describes the verification of old rights and new rights to become the first land registration requirement for sporadic and systematic land registration. The government made a program in 2017 to accelerate land registration in Indonesia so that the Ministerial Regulation Number 6 Year 2018 concerning Complete Systematic Land Registration was issued, but this Regulation was contrary to the Government Regulation Number 24 of 1997 concerning proof of both old and new rights. This Ministerial Regulation supersedes the land ownership letter as a history of land with a statement made by itself, if the land is lost or nonexistent. Second, the certificate of land rights issued under the Ministerial Regulation has positive and negative implications. The positive implications are related to the return of public trust in the BPN. Negative implications related to the land certificates and products issued with incomplete registration conditions will increase the likelihood of future land conflicts.
\end{abstract}

Keywords: Agrarian Reform; Certificate; Complete Systematic Land Registration

Abstrak: Tujuan penelitian adalah untuk mengetahui sinkronisasi Peraturan Pemerintah Nomor 24 tahun 1997 dengan Peraturan Menteri Nomor 6 Tahun 2018 dan Implikasi sertipikat hak atas tanah dengan adanya Peraturan Menteri Nomor 6 Tahun 2018 terhadap kepastian kepemilikan tanah tersebut. Hasil penelitian 
menunjukkan bahwa: Pertama, Peraturan Pemerintah Nomor 24 Tahun 1997 tentang Pendaftaran Tanah menjelaskan tentang pembuktian hak lama dan hak baru untuk menjadi syarat pendaftaran tanah pertama kali untuk pendaftaran tanah secara sporadik maupun secara sistematik. Pemerintah membuat suatu program pada tahun 2017 untuk percepatan pendaftaran tanah di Indonesia sehingga dikeluarkan Peraturan Menteri Nomor 6 Tahun 2018 tentang Pendaftaran Tanah Sistematis Lengkap, namun Peraturan ini bertentangan dengan Peraturan Pemerintah Nomor 24 tahun 1997 mengenai pembuktian hak baik yang lama maupun hak baru. Peraturan Menteri ini menggantikan surat pemilikan tanah sebagai riwayat tanah dengan surat pernyataan yang dibuat sendiri, apabila tanah tersebut bukti pemilikannya hilang atau tidak ada sama sekali. Kedua, sertipikat hak atas tanah yang terbit berdasarkan Peraturan Menteri tersebut menimbulkan implikasi positif dan negatif. Implikasi positifberkaitan dengan kembalinya kepercayaan masyarakat terhadap BPN. Implikasi negatif berkaitan dengan produk sertipikat tanah yang dikeluarkan dengan syarat pendaftaran yang tidak lengkap maka akan memperesar kemungkinan terjadinya konflik tanah kedepannya.

Kata Kunci: Reformasi Agraria; Sertipikat; Pendaftaran Tanah Sistematis Lengkap

\section{PENDAHULUAN}

Reforma Agraria (Pembaharuan Agraria), merupakan salah satu alat atau cara efektif untuk mewujudkan keberhasilan pembangunan, sebab akses terhadap tanah memiliki sifat yang fundamental bagi pembangunan sosial ekonomi dan bagi kelestarian lingkungan yang berkelanjutan.

Reforma Agraria menjadi salah satu penyokong program pemerintah membuat percepatan pendaftaran tanah demi terselenggaranya pembangunan berkelanjutan. Hal tersebutdikarenakan tanah menjadi modal utama pembangunan dan juga merupakan kebutuhan pokok yang menyangkut hajat hidup orang banyak.

Pendaftaran tanah di Indonesia dalam Undang-Undang Nomor 5 Tahun 1960 tentang Pokok-pokok Agraria merupakan awal dari proses lahirnya sebuah bukti kepemilikan hak atas tanah. Pendaftaran Tanah merupakan upaya pemerintah untuk mewujudkan keteraturan agar terciptanya pengelolaan agraria yang baik dan berujung kepada pembangunan yang berkelanjutan.

Menghadapi permasalahan kebutuhan manusia atas tanah yang semakin meningkat, sementara tanah tidak bertambah dan untuk menatanya, Pemerintah menyelenggarakan pendataan penguasaan tanah yang mutakhir, terutama untuk keperluan perpajakan, perencanaan dan pengawasan serta dibalik itu juga bagi masyarakat memberikan jaminan kepastian hukum mengenai hak-hak atas tanahnya. ${ }^{1}$

Tentang Reforma Agraria (Pembaharuan Agraria), merupakan salah satu alat atau cara efektif untuk mewujudkan keberhasilan pembangunan, sebab akses terhadap tanah memilik sifat yang fundamental bagi pembangunan sosial ekonomi dan bagi kelestarian lingkungan yang berkelanjutan. Salah satu pe-

1 IslinaYuliyanti, Yulia Qamariyanti, dan Mahyuni. 2018. "Akibat Hukum Keterlambatan Pendaftaran Peralihan Hak Atas Tanah Terhadap Akta Yang dibuat oleh Pejabat Pembuat Akta Tanah". Lambung Mangkurat Law Journal, 3(1): 97 
nyokong program pemerintah membuat percepatan pendaftaran tanah supaya terselenggaranya pembangunan berkelanjutan karena tanah menjadi modal utama pembangunan dan juga merupakan kebutuhan pokok yang menyangkut hajat hidup orang banyak

Pendaftaran tanah di Indonesia dalam Undang-Undang Nomor 5 Tahun 960 merupakan awal dari proses lahirnya sebuah bukti kepemilikan hak atas tanah. Begitu pentingnya persoalan pendaftaran tanah tersebut sehingga Undang-Undang Nomor 5 Tahun 960 memerintahkan kepada pemerintah untuk melakukan pendaftaran tanah di seluruh wilayah Indonesia. Untuk menjamin kepastian hukum oleh Pemerintah diadakan pendaftaran tanah diseluruh wilayah Republik Indonesia menurut ketentuan-ketentuan yang diatur dengan Peraturan Pemerintah.

Masalah hukum (legal problem) kemudian muncul ketika dalam kegiatan program yang lahir pada tahun 2017 berkaitan dengan pendaftaran tanah yang disebut Pendaftaran Tanah Sistematis Lengkap (PTSL). Program ini memberikan kemudahan dalam proses sertifikasi tanah dan bertujuan untuk percepatan pendaftaran tanah di Indonesiayang berkaitan dengan bukti kepemikan tanah dengan dikeluarkan Peraturan Menteri Agraria dan Tata Ruang Nomor 6 Tahun 2018 tentang Pendaftaran Tanah Sistematis Lengkap. Pada Pasal 22 Peraturan Menteri ini menyebutkan bahwa dalam hal bukti kepemilikan tanah masyarakat yang tidak lengkap atau tidak ada sama sekali maka dapat dilengkapi dan dibuktikan dengan surat pernyataan tertulis tentang penguasaan fisik bidang tanah dengan itikad baik oleh seseorang. Adanya ketidaksinkronan antara Peraturan Menteri ini dengan Peraturan Pemerintah Nomor 24 Tahun 1997 tentang Pendaftaran Tanah yang mengatur bukti pemilikan hak atas tanah yang akan didaftarkan.

Peraturan Menteri Agraria dan Tata $\mathrm{Ru}-$ ang Nomor 6 Tahun 2018 tentang Pendaftaran Tanah Sistematis Lengkap juga dapat menimbulkan suatu implikasi hukum yang sifatnya positif maupun negatif yang berkaitan dengan kebijakan yang dikeluarkan oleh Pemerintah untuk melakukan Percepatan Pendaftaran Tanah di Indonesia. Maka dari itu dapat dirumuskan permasalahan sebagai berikut:

a. Bagaimana sinkronisasi antara Peraturan Pemerintah Nomor 24 Tahun 1997 tentang Pendaftaran Tanah dengan Peraturan Menteri Agraria dan Tata Ruang Nomor 6 Tahun 2018 tentang Percepatan Pendaftaran Tanah Sistematis Lengkap?

b. Bagaimana implikasi sertipikat hak atas tanah yang terbit dengan berlakunya Peraturan Menteri Agraria dan Tata Ruang Nomor 6 Tahun 2018 tentang Percepatan Pendaftaran Tanah Sistematis Lengkap terhadap kepastian hukum?

\section{METODE}

\section{Jenis Penelitian}

Penelitian ini menggunakan jenis penelitian hukum normatif yaitu penelitian yang meletakkan sebagai sebuah bangunan sistem norma. $^{2}$

Peter Mahmud Marzuki menjelaskan penelitian normastif adalah: ${ }^{3}$

"Suatu proses untuk menemukan suatu aturan, prinsip-prinsip, maupun doktrin-doktrin untuk menjawab permasalahan yang dihadapi. Penelitian hukum normatif dilakukan untuk menghasilkan argumentasi, teori atau

2 Mukti Fajar ND danYulianto Achmad. 2010. Dualisme Penelitian Normatif dan Empiris, Pustaka Pelajar. Yogyakarta. hlm. 34.

3 Peter Mahmud Marzuki. 2005. Penelitian, Yogyakarta: Kencana, hlm. 35. 
konsep baru sebagai preskripsi dalam menyelesaikan masalah yang sedang dihadapi”.

\section{Tipe Penelitian}

Penulis memilih tipe Doctrinal Research yaitu secara sistematisasi mengkoreksi dan memperjelas suatu aturan yang berlaku pada bidang tertentu dengan cara melakukan analisis terhadap teks yang bersifat autoritatif yang meliputi bahan hukum primer dan bahan hukum sekunder. ${ }^{4}$ Dalam hal ini terjadi konflik norma antara Peraturan Pemerintah Nomor 24 Tahun 1997 tentang Pendaftaran Tanah dan Peraturan Menteri Nomor 6 Tahun 2018 tentang Pendaftaran Tanah Sistematis Lengkap.

\section{Pendekatan Penelitian}

Pendekatan yang digunakan sesuai dengan rumusan masalah dalam penelitian ini adalah pendekatan perundang-undangan (statute approach) dan pendekatan konseptual. Pendekatan undang-undang adalah pendekatan yang dilakukan dengan menelaah semua undang-undang dan regulasi yang bersangkut paut dengan isu yang diketengahkan. ${ }^{5}$ Penulis melakukan pendekatan terhadap Peraturan Pemerintah Nomor 24 Tahun 1997 tentang Pendaftaran Tanah dan Peraturan Menteri Nomor 6 Tahun 2018 tentang Percepatan Pendaftaran Tanah Sistematis Lengkap

\section{Sifat Penelitian}

Penelitian ini bersifat preskriftif analisis yaitu mempelajari tujuan, nilai-nilai keadilan, validitas aturan, konsep-konsep dan norma-

4 Dyah Ochtorina Susanti dan A'an Efendi. 2014. Penelitian (Legal Research). Jakarta: Sinar Grafika, hlm. 15.

5 Peter Mahmud Marzuki, Op. Cit, hlm. 93 norma. ${ }^{6}$ Penulis memberikan kritisi serta solusi atas permasalahan yang dikaji dan dianalisa dalam penelitian ini.

\section{Jenis Bahan Hukum}

Penelitian ini mengambil langkah penelitian dengan mengumpulkan bahan dengan melakukan studi kepustakaan (library research). Bahan hukum yang diperoleh dari penelitian kepustakaan adalah meliputi: bahan hukum primer, bahan hukum sekunder, dan bahan hukum tersier:

1. Bahan hukum primer, yaitu:

a. Undang-Undang Dasar Republik Indonesia 1945;

b. Kitab Undang-Undang Perdata, Staatsblad Tahun 1847 No. 23 diumumkan 30 April 1847;

c. Undang-Undang Nomor 5 Tahun 1960 tentang Pokok-Pokok Agraria

d. Peraturan Pemerintah Nomor 24 Tahun 1997 tentang Pendaftaran Tanah;

e. Peraturan Menteri Nomor 6 Tahun 2017 tentang Percepatan Pendaftaran Tanah Sistematis Lengkap;

2. Bahan hukum sekunder, yaitu bahan hukum yang memberikan penjelasan atau membahas lebih lanjut hal-hal yang diteliti oleh penulis pada bahan hukum primer. Bahan hukum sekunder ini meliputi buku-buku tentang perbankan, dokumen dari instansi-instansi terkait, karya ilmiah serta artikel-artikel yang berkaitan dengan permasalahan yang diteliti oleh penulis.

3. Bahan hukum tersier yaitu bahan hukum yang memberikan penjelasan mengenai bahan hukum primer dan bahan hukum sekunder yang meliputi: kamus Bahasa Indonesia, dan juga kamus lainnya.

$6 \quad$ Ibid, hlm. 22 


\section{Teknik Pengumpulan Bahan Hukum}

Untuk memperoleh bahan hukum yang relevan digunakan inventarisasi dan pengumpulan bahan dengan studi kepustakaan (library research). Pada studi lapangan dengan mencari dan mengumpulkan bahan-bahan bacaan yang berhubungan dengan masalah yang dibahas dalam tulisan ini seperti peraturan perundang-undangan, buku-buku, makalah, dan hasil-hasil penelitian yang relevan.

\section{Teknik Pengolahan Bahan Hukum}

Setelah bahan hukum dikumpulkan, kemudian tahap selanjutnya adalah melakukan pengolahan bahan hukum, yaitu mengelola bahan hukum sedemikian rupa sehingga bahan hukum tersebut tersusun secara runtut, sistematis, sehingga akan memudahkan penelitian melakukan analisis.

Bahan hukum yang terkumpul melalui kegiatan pengumpulan bahan hukum memberikan makna apapun bagi tujuan penelitian, oleh karena itu, setelah pengumpulan bahan hukum ini, penulis kemudian melakukan kegiatan pengolahan bahan hukum.

\section{Teknik Analisis Bahan Hukum}

Melakukan analisa bahan hukum merupakan kegiatan dalam penelitian dengan melakukan kajian atau telaah terhadap hasil pengolahan bahan hukum yang dibantu dengan teori-teori yang telah didapatkan sebelumnya. Secara sederhana analisis bahan ini disebut sebagai kegiatan memberikan telaah, yang dapat berarti menentang, mengkritik mendukung, menambah atau memberi komentar dan kemudian membuat suatu kesimpulan terhadap hasil penelitian.

\section{ANALISIS DAN PEMBAHASAN Sinkronisasi Antara Peraturan Pemerin- tah Nomor 24 Tahun 1997 tentang Pendaf- taran Tanah dengan Peraturan Menteri Nomor 6 Tahun 2018 tentang Percepatan Pendaftaran Tanah Sistematis Lengkap}

Dalam kegiatan pengumpulan data yuridis dalam kegiatan pendaftaran tanah diadakan perbedaan antara pembuktian hak-hak baru dan hak lama untuk Pendaftaran Tanah. Hak hak baru adalah hak yang baru diberikan atau diciptakan sejak mulai berlakunya UndangUndang Nomor 5 Tahun1960 jo. Peraturan Pemerintah Nomor 10 Tahun 1961. Sedangkan hak lama yaitu hak atas tanah yang berasal dari konversi hak-hak yang ada pada waktu mulai berlakunya UUPA dan hak-hak yang belum didaftarkan menurut Peraturan Pemerintah Nomor 10 Tahun 1961. Di dalam Pasal 23 dan 24 Peraturan Pemerintah Nomor 24 Tahun 1997 sudah sangat terperinci menjelaskan mengenai bagaimana pembuktian hak lama maupun hak baru untuk keperluan pendaftaran tanah. Namun dengan dikeluarkanya Peraturan Menteri Agraria dan Tata Ruang Nomor 6 Tahun 2018 maka tidak berlaku lagi pembuktian Hak lama maupun Hak baru untuk keperluan pendaftaran tanah dalam hal pemilik Tanah tidak mempunyai bukti kepemilikan hak atas tanah, maka hanya digantikan dengan surat keterangan yang ditandatangani oleh 2 orang saksi sebagai dasar kepemilikan hak atas tanah.

Permasalahan hukum mengenai akibat hukum terhadap tindakan pemerintah menggantikan surat pemilikan hak atas tanah yang dikeluarkan oleh Lurah digantikan dengan surat pernyataan ditanda tangani oleh 2 orang saksi sesuai dengan Peraturan Menteri Agraria dan Tata Ruang Nomor 6 Tahun 2018 yang bertentangan/melanggar Peraturan Pemerin- 
tah Nomor 24 Tahun 1997 dapat dikatakan Pendaftaran Tanah yang menggunakan surat pernyataan tersebut dapat dikatakan sebagai perbuatan yang cacat hukum.

Pihak Badan Pertanahan Nasional yang berwenang dalam hal menerima permohonan Pendaftaran Tanah yang diajukan oleh pemohon haruslah benar-benar memeriksa kelengkapan berkas permohonan pendaftaran tanah sesuai dengan aturan yang berlaku, dan dapat dipertanggung jawabkan kebenaran dari berkas permohonan tersebut agar tidak terjadi suatu konflik/masalah di kemudian hari setelah terbitnya suatu produk hukum yaitu sertipikat hak atas tanah.

\section{Implikasi Sertipikat Hak Atas Tanah yang Terbit dengan Berlakunya Peraturan Menteri Agraria dan Tata Ruang Nomor 6 Tahun 2018 Tentang Percepatan Pendaf- taran Tanah Sistematis Lengkap Terhadap Kepastian Hukum Kepemilikan Tanah.}

Dalam hal bukti kepemilikan tanah masyarakat yang tidak lengkap atau tidak ada sama sekali maka dapat dilengkapi dan dibuktikan dengan surat pernyataan tertulis tentang penguasaan fisik bidang tanah dengan itikad baik oleh seseorang merupakan isi dari Pasal 22 ayat 2 Peraturan Menteri Agraria Nomor 6 Tahun 2018. Hal ini sudah menyalahi syarat sah pendaftaran tanah yang sudah di atur oleh Pasal 23 dan Pasal 24 Peraturan Pemerintah Nomor 24 Tahun 1997 tentang pembuktian hak lama dan hak baru, menimbulkan implikasi positif dan negatif terhadap kepastian kepemilikan tanah.

Implikasi positif pertama yang bisa didapat dengan adanya pengurusan dan pemilikan sertipikat tanah yang syarat pendaftaran tanahnya dipermudah yaitu adanya kepastian hukum hak atas tanah. Dengan adanya bukti sertipikat hak atas tanah yang terbit berdasarkan peraturan tersebut, maka kepastian hukum dijamin di hadapan hukum dan perundang-undangan. Masyarakat dengan mudah mendaftarkan tanahnya dan mendapatkan sertipikat hak atas tanah dengan syarat yang di permudah.

Implikasi positif kedua adalah terciptanya kepercayaan masyarakat terhadap Badan Pertanahan Nasional dalam mengurus sertipikat tanah. Dengan adanya pelayanan yang prima oleh petugas badan pertanahan nasional, selain memberikan dampak positif bagi kepastian hukum dan kenyamanan masyarakat, juga menjadi jaminan kepercayaan masyarakat terhadap lembaga Negara.

Masyarakat dengan sendirinya akan memberikan kepercayaan penuh kepada pihak Badan Pertanahan Nasional untuk membantu mereka dalam upaya melegalkan semua hak milik tanah yang dimiliki tanpa adanya praduga atau pikiran negatif. Jaminan kepercayaan masyarakat ini akan semakin mempermudah kinerja Badan Pertanahan Nasional dalam upaya menciptakan stabilitas bagi warga masyarakat.

Hal ini tentu dengan sendirinya akan memudarkan pra anggapan masyarakat tentang lembaga Negara ini yang menurut mereka adalah sarana 'pungli' (pungutan liar) uang rakyat dengan modus pengurusan suratsurat sertipikat tanah atau sarana dikte bagi masyarakat dan lain sebagainya. Kesan ini berubah dengan sendirinya sejalan dengan perbaikan kinerjapetugas Badan Pertanahan Nasional dalam menangani proses pembuatan sertipikat tanah dari masyarakat. Asa keadilan dan jaminan penegakan hukum menjadi kunci keberhasilan kinerja Badan Pertanahan Nasional dan kunci kembalinya kepercayaan masyarakat terhadap lembaga Negara bidang 
pertanahan.

Implikasi negatif pertama yang bisa terjadi dengan pengurusan sertipikat hak atas tanah dengan peraturan tersebut. Berdasarkan ketentuan umum yang berlaku bahwa setiap hak kepemilikan yang diperoleh dengan didasarkan kepada alas hak yang diterbitkan dengan cara melawan hukum maka penerbitan kepemilikan hak atas tanah tersebut mengandung cacat hukum. Sertipikat hak atas tanah adalah suatu produk Pejabat Tata Usaha Negara (TUN), sehingga atasnya berlaku ketentuanketentuan hukum administrasi Negara. Atas perbuatan hukum tersebut seseorang selaku pejabat TUN dapat saja melakukan perbuatan yang terlingkup sebagai perbuatan yang melawan hukum baik karena kesalahan maupun akibat kelalaian menjalankan kewajiban hukumnya. ${ }^{7}$ Terkait surat pernyataan yang menggantikan Surat Pemilikan Hak atas tanah yang dikeluarkan oleh kepala desa/kelurahan suatu daerah tersebut yang menjadi dasar pendaftaran tanah sistematik lengkap tersebut yang di tandatangani oleh 2 orang saksi tidak memenuhi syarat sah di terbitkan nya sertipikat. Karena surat pernyataan tersebut bisa saja di buat tidak berdasarkan kenyataan sebenarnya terkait data fisik bidang tanah dan data mengenai kepemilikan tanah tersebut.

Atas perbuatan yang salah atau lalai akhirnya akan menghasilkan produk hukum sertipikat yang salah pula, baik kesalahan atas subjek hukum dalam sertipikat, maupun kesalahan atas hukum dalam sertipikat tersebut. Kesalahan mana telah ditenggarai dapat terjadi dalam berbagai proses pendaftaran tan-

7 Ali Achmad Chomzah. 2003. Hukum Agraria (Pertanahan) Indonesia Jilid 1. Jakarta: Prestasi Pustaka, hlm.1-5 ah. ${ }^{8}$ Oleh karena itu, seorang pejabat TUN perlu hati-hati dan teliti dalam menghadapi tugasnya untuk mengurusi berbagai permohonan masyarakat dalam mengurus sertipikat dan atau surat tanah. ${ }^{9}$ Kesalahan bisa saja dalam hal pembuatan data fisik maupun data yuridis yang dibukukan dalam buku tanah. Akibat dari kesalahan dan kelalaian ini, maka sertipikat yang dihasilkan pun bisa batal demi hukum. Adapun bagi subjek yang melakukan hal tersebut dapat dikatakan telah melakukan perbuatan melawan hukum. Apabila perbuatan dilakukan oleh alat-alat perlengkapan Negara/Badan Pertanahan Nasional, maka perbuatan tersebut dapat dikategorikan sebagai penyalahgunaan kewenangan dari pejabat Tata Usaha Negara.

Implikasi negatif kedua yang bisa didapat dengan adanya pendaftaran tanah dengan syarat yang tidak lengkap adalah terjadinya kriminalisasi. Kriminalisasi bisa terjadi pada pihak PTUN dan juga pada pihak pemohon. Hal ini sebagai akibat dari kekurangtelitiannya pejabat maupun niat jahat dari pemohon pembuat sertipikat dalam pengurusan. Hal ini tentu akan memberikan efek negatif bagi penegakan hukum di Indonesia. Pasal 52 Undang-Undang Nomor 5 Tahun 1960 telah mengamanatkan penegakan hukum, dan bidang pendaftaran tanah dapat dikenakan sanksi pidana atas perbuatan-perbuatan tertentu. Peraturan pelaksanaan dari ketentuan ini dirumuskan dalam Peraturan Pemerintah Nomor 10 Tahun 1961 tentang Pendaftaran Tanah. Peraturan Pemerintah ini menggariskan kebijakan kriminalisasi yang dirumuskan dalam Peraturan Pemerintah Nomor 10 Tahun 1961 dengan tegas menentukan bahwa sanksi

\footnotetext{
8 Amal Bahrul. 2017. Hukum Tanah Nasional, Jakarta: Thafa Media, hlm.12

$9 \quad$ Ibid, hlm. 16
} 
pidana terhadap pelanggaran batas-batas dari suatu bidang tanah dinyatakan dengan tandatanda batas menurut ketentuan yang ditetapkan oleh Menteri Agraria. ${ }^{10}$

Implikasi negatif yang ketiga yang bisa didapat dengan adanya pengurusan dan pemilikan sertipikat tanah dengan syarat hanya dengan surat pernyataan yang menggantikan surat tanda bukti pemilikan tanah, adalah akan terjadinya konflik atau pertikaian akibat status sertipikat yang tidak jelas dan atau sertipikat ganda. Dengan bantuan layanan sistem pengurusan surat tanah sebagaimana dijelaskan di atas, maka akan semakin memperbesar kemungkinan adanya sertipikat ganda atau klaim sertipikat yang dilakukan oleh pihak lain terhadap hak kepemilikan tanah yang dimiliki secara sah oleh perseorangan atau badan hukum. ${ }^{11}$

Implikasi negatif keempat Perbuatan hukum Pemerintah/Badan Pertanahan Nasional dalam melakukan pendaftaran tanah dan menerbitkan sertipikat sebagai suatu perbuatan hukum, untuk menimbulkan keadaan hukum baru dan melahirkan hak-hak serta kewajiban-kewajiban hukum baru terhadap orang/ subyek hukum tertentu, harus memenuhi syarat-syarat dan tidak boleh mengandung unsur kesalahan baik menyangkut aspek teknis pendaftaran tanah maupun aspek yuridis. Kesalahan dalam hal ini berakibat batal atau dapat dibatalkan.

Kesalahan data fisik maupun data yuridis dalam pendaftaran tanah akan menghilangkan unsur kepastian hukum hak atas tanah, sehingga orang yang berhak terhadap tanah

10 Petrus Sinaga, "Kepastian Hukum Sertipikat Hak Atas Tanah", dil/https://media.neliti.com/ media/publications/164983-ID-kepastian-hukumsertipikat-hak-atas-tanah.pdf, diakses Tanggal5 Mei 2018

11 Amal Bahrul, Op. Cit, hlm.45 tersebut akan dirugikan. Kesalahan juga akan berakibat terjadinya informasi yang salah di Badan Pertanahan Nasional sebagai alat kelengkapan negara yang akibatnya juga berarti menciptakan administrasi pertanahan yang tidak tertib. ${ }^{12}$

\section{PENUTUP}

Terhadap bidang tanah yang berasal dari hak-hak lama maupun hak baru untuk dapat didaftarkan hak atas tanahnya di Kantor Pertanahan maka kepala desa memiliki kewenangan untuk menerbitkan surat keterangan tanah sebagai alat bukti dalam pendaftaran tanah dalam pelaksanaan pendaftaran tanah untuk memperoleh sertipikat hak atas tanah di Kantor Pertanahan tempat dimana tanah tersebut berada. Maka surat pernyataan yang menggantikan alat bukti pemilikan tanah yang tercantum pada Pasal 22 ayat 2 Peraturan Menteri Agraria Nomor 6 Tahun 2018 sudah bertentangan dengan Peraturan Pemerintah yang mengatur tentang pendaftaran tanah dan pembuktian hak atas tanah. Tidak adanya sinkronisasi antara 2 peraturan ini membuat kerancuan hukum untuk aturan pendaftaran tanah. Dan dapat membuat produk hukum yang diterbitkan oleh Badan Pertanahan Nasional dalam hal ini sertipikat merupakan produk yang cacat administrasi hukum karena tidak sesuai dengan peraturan pendaftaran tanah.

Implikasi terhadap sertipikat hak atas tanah yang terbit setelah adanya Peraturan Menteri Agraria dan Tata Ruang Nomor 6 Tahun 2018 ini memberikan kepastian hu-

12 Syafruddin Kalo. "Aspek dan Implikasi Hukum dalam Pendaftaran Tanah dan Penertiban Sertipikat Hak-Hak atas Tanah", dil \http://www. hukumonline.com/berita/baca/hol19216/aspekdan-implikasi-hukum-dalam-pendaftaran-tanahdan-penertiban-sertipikat-hak-hak-atas-tanah, diakses Tanggal5 Mei 2018 
kum kepada masyarakat, dan terciptanya kepercayaan masyarakat terhadap Badan Pertanahan Nasional dalam mengurus sertipikat Tanah. Dengan adanya pelayanan yang prima oleh petugas badan pertanahan nasional, selain memberikan dampak positif menjadi jaminan kepercayaan masyarakat terhadap lembaga Negara. Akan tetapi dampak negatif yang mengiringi peraturan menteri tersebut juga tidak bisa dianggap sepele seperti, akan menghasilkan produk hukum sertipikat yang salah pula, baik kesalahan atas subjek hukum dalam sertipikat, maupun kesalahan atas hukum dalam sertipikat.

Hendaknya setiap bidang tanah yang memiliki alat bukti penguasaan fisik berupa surat keterangan tanah yang dikeluarkan oleh pihak yang berwenang sesuai dengan Peraturan Pemerintah Nomor 24 Tahun 1997 yang bisa didaftarkan didaftarkan di kantor pertanahan tempat dimana tanah tersebut berada untuk memperoleh sertipikat hak atas tanah tersebut sehingga lebih menjamin kebenaran pemilik tanah secara subyektif dan obyektif terhadap pemegang hak atas tanah tersebut atau pihak yang menguasai fisik tanah tersebut sesuai dengan ketentuan hukum yang berlaku. Dan apabila digantikan dengan surat pernyataan maka surat tersebut sebaiknya tetap dilegalisir oleh pihak Kelurahan.

Hendaknya Kebijakan pemerintah dengan semangat percepatan penyertipikatan tanah baiknya tetap memperimbangkan kepastian hukum, maka dari itu seharusnya, terdapat riwayat tanah sebagai dokumen lampiran surat keterangan tanah dalam pengurusan sertipikat tanah, bukan dengan menghapus surat keterangan tanah yang bersifat faktual dan objektif berdasarkan pada data,dengan alasan semangat percepatan penyertipikatan tanah dan menggantikan dengan surat penguasaan bidang fisik atas tanah yang bersifat lebih subyektif dan lebih memiliki potensi untuk menimbulkan kerugian pihak-pihak yang berkepentingan.

\section{BIBLIOGRAFI}

Bahrul, Amal. 2017. Hukum Tanah Nasional, Jakarta: Thafa Media

Chomzah, Ali Achmad. 2003. Hukum Agraria (pertanahan) Indonesia Jilid 1. Jakarta: Prestasi Pustaka

Kalo, Syafruddin. "Aspek dan Implikasi Hukum dalam Pendaftaran Tanah dan Penertiban Sertipikat Hak-Hak atas Tanah", di \http://www.hukumonline.com/berita/ baca/hol19216/aspek-dan-implikasihukum-dalam-pendaftaran-tanah-danpenertiban-sertipikat-hak-hak-atas-tanah, diakses Tanggal 5 Mei 2018

Marzuki, Peter Mahmud. 2005. Penelitian, Yogyakarta: Kencana

ND, Mukti Fajar danYulianto Achmad. 2010. Dualisme Penelitian Normatif dan Empiris, Yogyakarta: Pustaka Pelajar

Sinaga, Petrus."Kepastian Hukum Sertipikat Hak Atas Tanah", dil\https://media. neliti.com/media/publications/164983ID-kepastian-hukum-sertipikat-hak-atastanah.pdf, diakses Tanggal 5 Mei 2018

Susanti, Dyah Ochtorina dan A'an Efendi. 2014. Penelitian (Legal Research). Jakarta: Sinar

Yuliyanti, Islina, Yulia Qamariyanti dan Mahyuni. 2018. "Akibat Hukum Keterlambatan Pendaftaran Peralihan Hak Atas Tanah Terhadap Akta Yang dibuat oleh Pejabat Pembuat Akta Tanah" Lambung Mangkurat Law Journal, 3(1): 97

\section{Peraturan Perundang-undangan}

Undang-Undang Pokok Agraria Nomor 5 Tahun 1960 Tentang Pokok-pokok Agraria 
Peraturan Pemerintah Nomor 24 Tahun 1997 Tentang Pendaftaran Tanah

Peraturan Menteri Agraria Nomor 3 Tahun 1997 Tentang Petunjuk Pelaksanaan Pendaftaran Tanah
Peraturan Menteri Agraria Nomor 6 Tahun 2018 Tentang Pendaftaran Tanah Sistematis Lengkap. 